\title{
Detection of Muscle Dysmorphia symptoms in male weightlifters
}

\author{
Andrea Hernández-Martínez*, Irene González-Martí and Onofre Ricardo Contreras Jordán
}

Universidad de Castilla-La Mancha (Spain).

\begin{abstract}
Título: Detección de síntomas de dismorfia muscular en halterófilos masculinos.

Resumen: La Dismorfia Muscular (DM) es un desorden dismórfico corporal en el que la persona que lo padece está insatisfecho con su tamaño corporal, y/o forma. La DM no ha sido estudiada en halterófilos, por lo que el objetivo de esta investigación fue detectar síntomas en 32 halterófilos varones, así como características y comportamientos asociados. Este estudio requirió la cumplimentación de un cuestionario sociodemográfico además de una Escala de Satisfacción Muscular, un Cuestionario de Autoconcepto Físico y el Somatomorpic Matrix, así como el registro de las medidas antropométricas de los participantes. Los resultados revelaron la existencia de insatisfacción muscular entre los deportistas además del uso de sustancias con el objetivo de hacer crecer su musculatura y mejorar su rendimiento, comportamientos obsesivos con el fin de comprobar su musculatura, y bajas puntuaciones en autoconcepto físico como consecuencia de la insatisfacción muscular que sufrían. Se puede concluir que esta investigación confirma la existencia de DM en esta modalidad deportiva.
\end{abstract}

Palabras clave: Dismorfia Muscular; halterófilos; varones; insatisfacción muscular.

\section{Introduction}

Muscle dysmorphia (MD) is a body dismorfic disorder (APA, 2014) in which the sufferer is excessively concerned and dissatisfied with the size and shape of their muscles (Pope, Phillips \& Olivardia, 2000; González-Martí, Fernández \& Contreras, 2012). The muscle mass therefore becomes an indicator of DM, one of the variables in the development of this, which is calculated by means of the Fat Free Mass Index (FFMI; Kouri, Pope, Katz \& Oliva, 1995). The product of this equation, which is described in a later section, reveals if the muscles of a person are the result of steroid use.

As some research studies have shown, MD is common in sports such as bodybuilding (Esco, Olson \& Williford, 2005; González-Martí, 2012), in which competitors are assessed on the basis of their physique. MD has been found to be highly prevalent among this population (Esco et al., 2005), even in women (González-Martí, 2012). The disorder has not been studied in the sport of weightlifting, however, despite it being a discipline in which strength, and therefore a muscular physique, is of paramount importance, as a conditional capability that is central to performance.

In addition, and in spite of the fact that weightlifters train with the objective of lifting large weights and not for aesthetic purposes, it is probable that MD symptoms will appear in such athletes, as both muscle mass and strength are factors that are vital to performance in the sport (Barghurst \&

* Correspondence address [Dirección para correspondencia]:

Andrea Hernández-Martínez. Facultad de Educación. Departamento de Educación Física. Edificio Fray Luis de León. Campus Universitario, s/n. 16071. Cuenca (Spain). E-mail: Andrea.hernandez@uclm.es
Abstract: Muscle dysmorphia (MD) is a body dismorphic disorder in which the sufferer is dissatisfied with their body size and shape. MD has yet to be studied in weightlifters, and the objective of this research study is to detect its symptoms in 32 male weightlifters as well as any related characteristics and behaviours. This study involved the distribution of a sociodemographic questionnaire in addition to the Escala de Satisfacción Muscular, the Physical Self-Concept Questionnaire, and the Somatomorphic Matrix, with the anthropometric measurements of the participants also being recorded. The results revealed the existence of body dissatisfaction among athletes and, in some cases, muscle perception that does not equate to reality. The athletes also use substances to build their muscles and enhance their performance, display obsessive muscle checking behaviours, and have low general physical self-concept that stems from their muscle (dis)satisfaction. To conclude, this study confirms the existence of MD in this sport.

Key words: Muscle Dysmorphia; weightlifters; males; muscle dissatisfaction.

Lirrgg, 2009; Cafri, Van den Berg \& Thompson, 2006; Hale, Roth, Delong \& Briggs, 2010). Given that their training mainly involves explosive strength and coordination work, weightlifters have a high FFMI, a factor linked to the use of anabolic-androgenic steroids (AAS), which are commonly used by bodybuilders and weightlifters (Cafri et al., 2005). The consumption of AAS is another of the symptoms of MD (Babusa, Urbán, Czeglédi \& Túry, 2012). It has been shown that they contribute to an increase in musculature and help alleviate any muscle dissatisfaction felt by the sufferer.

Given the lack of studies on MD in male weightlifters and the demonstrated links between performance, strength and FFMI, the purpose of this research study is to detect the presence of MD symptoms in the sport as well as characteristics and behaviours related. With this in mind, four hypotheses were put forward, the first is that an activity in which muscular development is a key factor, as it is the case of weightlifting, some athletes will show symptoms of DM (Grive, 2007), as it may be muscular distortion and body dissatisfaction as a result.

The second hypothesis was that athletes affected by DM will use substances such as muscle-building supplements and fat burners to alleviate the body distortion from which they suffer. The third hypothesis put forward was that weightlifters suffering from MD will engage in obsessive muscle checking behaviours in an effort to detect any increase in muscle size, while the fourth was that participants with MD will have low general physical self-perception as a result of said muscle dissatisfaction. 


\section{Method}

\section{Design}

The nature of this research is descriptive and correlational. It explores the relationships of variables related to the $\mathrm{DM}$ in a sample of weightlifters males, due to scarce literature published on the subject.

\section{Participants}

Thirty-two male weightlifters aged between 13 and $40(M$ $=23.22, S D=7.99)$ took part in the study. This relatively small sample size can be explained by the low number of weightlifters currently registered with accredited clubs and the difficulty in gaining access to these clubs. Some $96 \%$ of participants were heterosexual, while the remaining $4 \%$ did not provide information about their sexual orientation. In terms of ethnic backgrounds, $97 \%$ of the participants were Caucasian and $3 \%$ were African. The average height was $1.71 \mathrm{~m}(S D=6.15)$, while the average weight was $76.55 \mathrm{~kg}$ $(S D=12.88)$. In terms of body fat and FFMI, the averages were $12.85 \%(S D=5.42)$ and $22.38 \mathrm{~kg} / \mathrm{m}^{2}(S D=2.60)$ respectively. Of the eight weight categories recognised by the International Weightlifting Federation (IWF), the athletes ranged between one and six (from $56 \mathrm{~kg}$ to $94 \mathrm{~kg}$ ). The number of hours devoted to training every week varied, depending on the level of the athletes $(M=10.65, S D=8.45)$, and was influenced by the category in which they compete and their attendance of regional, continental and world championships.

\section{Measures}

Measuring the participant's current body fat percentage. To ascertain this, the heights and weights of the participants were measured using a portable SECA 206 height measure and digital scales (SECA, Hamburg, Germany), with the units of measurement of the international metric system being used to record them. A glass fibre metric tape was also used to measure limb circumferences and a skin fold calliper (AW610 Holtain) for skin folds. Data was taken from six folds (triceps, subscapular, chest, supraspinal, abdominal and anterior thigh), in accordance with Jackson and Pollock's formula (1978): ( $[\%$ body fat $=.217 \mathrm{x}-$ $\left.\left..00029 x^{2}+.133 y-5.73\right]\right)$, where the unknown " $x$ " is the sum of the skin folds and " $y$ " the age of the participant.

Measuring the participant's current level of muscularity. The Fat-Free Mass Index (FFMI; Kouri, et al., 1995) was applied in order to provide information on the current level of muscularity. It uses the following formula: [weight (100 - \%body fat) / 100)/ height ${ }^{2}+6.1$ (1.8 - height $\left.)\right]$, with the athlete's real FFMI being calculated as a result. According to Pope et al. (2000), the results it yields should be interpreted as follows: $16-17 \mathrm{~kg} / \mathrm{m}^{2}$ represents a man with a low level of muscularity, $19-20 \mathrm{Kg} / \mathrm{m}^{2}$ is equivalent to the typical body of a young man, $22-23 \mathrm{~kg} / \mathrm{m}^{2}$ equates to the body of a particularly muscular man, and $25 \mathrm{~kg} / \mathrm{m}^{2}$ and above represents the maximum limit of muscularity that can be achieved without using steroids. For its part, body fat was calculated using the formula quoted in the previous section.

Measuring body image. The Somatomorphic Matrix (Gruber, Pope, Borowiecki \& Cohane, 1999), bidimensional software that assesses an individual's body image in relation to their muscularity and body fat, was used to measure this variable. Information on weight, height and real FFMI (Kouri et al., 1995) is required for it to be administered. The instrument is comprised of 100 images arranged in a ten $\mathrm{x}$ ten matrix, showing ten different levels of body fat and ten levels of FFMI. The athlete is required to modify a series of images in accordance with their body image and a series of five statements, the first two of which were considered for this study. As a result, their perceived FFMI and body fat is ascertained in addition to their desired FFMI and body fat. Three new variables were also created for this research study in order to detect the discrepancy between real and perceived FFMI, real and desired FFMI, and perceived and desired FFMI (González-Martí, 2012; González-Martí, Fernández, Hernández-Martínez \& Contreras, 2014).

Detection of muscle dysmorphia symptoms. The Escala de Satisfacción Muscular (ESM; González-Martí, Fernández, Contreras \& Mayville, 2012) which comprises 19 items corresponding to five variables linked to muscle (dis)satisfaction, bodybuilding dependence, muscle checking, substance use and injury, was administered for this purpose. Answers are rated using a 5-point Likert-type scale ranging from 1 (totally disagree) to 5 (totally agree). Items 1, 4 and 14 are rated in an inverse manner as they are written using negative constructions. The result of the test is calculated by adding up the scores for each item, with muscle dissatisfaction categories being created in accordance with the points totals. The categories range from 19 to 95 points. Participants scoring between 19 and 39 points (category 1) are deemed to be satisfied with their muscularity, those scoring between 40 and 57 (category 2) are slightly dissatisfied, those scoring between 58 and 76 (category 3) are moderately dissatisfied, and those scoring over 77 (category 4) are identified as suffering from MD (González-Martí et al., 2014). The questionnaire had a Cronbach's alpha of .63 .

Assessment of muscle checking behaviours and the use of ergogenic substances. A demographic questionnaire comprising 28 items was used. Closed questions were asked for 14 of these items, with between two and eight answer options being given (e.g. "Have you ever taken weightgain supplements or pills?", "How many times for day do you look at yourself in the mirror?"). Open questions were asked for the rest of the items, giving participants the opportunity to provide more extensive answers (e.g. "What type of pills or supplements have you taken?", "How do you check that a physical improvement has taken place?"). The items making up the research instrument encompass a number of 
aspects ranging from sexual preference, the number of hours dedicated to physical exercise and body image.

Measurement of physical self-concept. Participants were asked to complete the Cuestionario de Autoconcepto Físico (CAF; Goñi, Ruiz de Azúa \& Liberal, 2004) for this purpose. The CAF comprises 36 items with answers being rated using a 5 point Likert type scale ranging from 1 (false) to 5 (true), allowing scores to be obtained for each specific subdomain of physical self-concept, in accordance with Fox and Corbin's model (1989): sport ability, physical condition, physical attractiveness and strength, in addition to two general subdomains, namely general self-concept and general physical self-concept. This research instrument had a Cronbach's alpha of 92 .

\section{Procedure}

The criteria for the selection of participants were that they must belong to one of the three age groups recognised by the IWF (youth, junior and senior) and that they must have taken part in regional, continental or world championships. Sports clubs were assessed as to their suitability for the research study, with the managers of these clubs then being contacted and the purpose of the study explained to them. Once they had given their permission and the requisite facilities had been made available, each participant signed an informed consent form explaining the objective of the research study. In the case of minors, the document was signed by their legal guardians. Data was gathered using the International Society for the Advancement of Kinanthropometry protocol (ISAK; Marfell-Jones, Olds, Stewart \& Carter, 2006), with height and weight measurements being taken at the start of the day. Anthropometric measurements were then taken. Information relating to the body fat on selected folds was recorded and the percentage total body fat of the participants was calculated by applying this data to Jackson and Pollock's formula (1978). The participants then completed the following research instruments: a demographic questionnaire, the Escala de Satisfacción Muscular (ESM; González-Martí et al., 2012), the Cuestionario de Autoconcepto Físico (CAF; Goñi et al., 2004), and the Somatomorphic Matrix (Gruber et al., 1998). Each athlete took less than 20 minutes to provide data.

\section{Statistics analysis}

Data was analysed using descriptive techniques for presenting the basic characteristics of the variables under consideration (body image and body satisfaction of the participants, substance use, behaviours associated with weight control and the checking/comparing of muscularity, and physical self-concept), in accordance with the ESM categories. Selected in light of the number of participants and the failure to meet the criteria of sample normality, the Wilcoxon signed rank test was used to compare averages by taking the real FFMI, perceived FFMI and desired FFMI into considera- tion. Finally, bivariate correlations (Rho de Spearman) were used to determine the extent to which the data extracted from the ESM and CAF questionnaires responded to the research hypothesis, all with the assistance of SPSS Statistics 20.

\section{Results}

\section{Detection of Muscle Dysmorphia}

Table 1 reports the results of the Wilcoxon signed rank test for the entire sample, where it is shown that all the participants have a real FFMI (Kouri et al., 1995) that is greater than their perceived FFMI and that they all want their real FFMI to be higher. Twenty of the participants, some $62.5 \%$ of the sample, also want a higher FFMI than their perceived FFMI.

Table 1. Comparisons between Real, Perceived and Desired FFMI $(n=$ 32).

\begin{tabular}{lccc}
\hline & 1 & 2 & 3 \\
\hline Negative ranges & $0^{\mathrm{a}}$ & $32^{\mathrm{a}}$ & $5^{\mathrm{a}}$ \\
Positive ranges & $32^{\mathrm{b}}$ & $0^{\mathrm{b}}$ & $20^{\mathrm{b}}$ \\
Draws & $0^{\mathrm{c}}$ & $0^{\mathrm{c}}$ & $7 \mathrm{c}$ \\
\hline Negative average range & .00 & 16.50 & 8.70 \\
Sum of negatives ranges & .00 & 528.00 & 43.50 \\
\hline Positive average range & 16.50 & .00 & 14.08 \\
Sum of positives ranges & 528.00 & .00 & 281.50 \\
\hline
\end{tabular}

Note: $1^{\mathrm{a}}$ Real FFMI < Perceived FFMI. $1^{\mathrm{b}}$ Real FFMI $>$ Perceived FFMI. $1^{\mathrm{c}}$ Real FFMI $=$ Perceived FFMI. $2^{\mathrm{a}}$ Desired FFMI $<$ Real FFMI. $2^{\mathrm{b}}$ Desired FFMI $>$ Real FFMI. 2c Desired FFMI $=$ Real FFMI. 3a Desired FFMI $<$ Perceived FFMI. $3^{\mathrm{b}}$ Desired FFMI $>$ Perceived FFMI. $3^{\mathrm{c}}$ Desired FFMI $=$ Perceived FFMI.

In line with the Escala de Satisfacción Muscular, participants were categorized as follows: $34.4 \%$ said they were satisfied with their muscularity (category 1), 59.4\% expressed slight dissatisfaction with their muscularity (category 2), and $6.3 \%$ said they were moderately dissatisfied with their muscularity, which placed them in category 3 and revealed them to have muscle dysmorphia symptoms and to be a population at risk.

Table 2 shows how the participants in category 3 have a higher real FFMI $\left(M=22.80 \mathrm{~kg} / \mathrm{m}^{2}\right)$ and a lower perceived FFMI $\left(M=15 \mathrm{~kg} / \mathrm{m}^{2}\right)$ than the rest of the athletes, revealing a distortion of $7.8 \mathrm{~kg} / \mathrm{m}^{2}$ in terms of the level of muscle development. This is supported by the fact that the desired FFMI of the participants in this category is smaller than their real FFMI.

Table 2. Descriptive of FFMI variables according to the ESM categories.

\begin{tabular}{lcccccc}
\hline & \multicolumn{2}{c}{ Category 1} & \multicolumn{2}{c}{ Category 2} & \multicolumn{2}{c}{ Category 3 } \\
\cline { 2 - 7 } & $M$ & $S D$ & $M$ & $S D$ & $M$ & $S D$ \\
\hline Real FFMI & 22.30 & 3.62 & 22.38 & 1.86 & 22.80 & 4.10 \\
Perceived FFMI & 17.70 & 1.81 & 18.78 & 1.93 & 15 & 2.82 \\
Desired FFMI & 20.16 & 1.55 & 23.34 & 1.51 & 22.5 & .70 \\
\hline
\end{tabular}




\section{Substance use}

The frequency analysis revealed that all the category 3 participants, namely those who scored 58 points or more in the ESM and are moderately dissatisfied with their muscularity, consume some type of weight-gain supplement on a daily basis or twice a week. These substances are carbohydrate and protein shakes, which are consumed in the recommended amounts. It is these participants who spend most on substances and who would also try any type of product in order to increase their muscularity.

\section{Muscle checking behaviours}

All the participants were agreed that the exercise they engage in helps improve their physique, though not all of them said that they check to see that this improvement actually takes place. With regard to the frequencies of the athletes belonging to ESM category 3, it was found that they look in the mirror to check any changes in their physical appearance, doing so three times a day or "as often as they can", both before and after training. Half of these participants check their weight once or twice a day and the same number also acknowledged that they compare their bodies to those of their colleagues, stating that they do so "too many times a day".

\section{Physical Self-concept}

As regards self-concept, the perceptions of the ESM category 3 participants, athletes who are moderately dissatisfied with their muscularity, are lower than those of the other athletes, as can be seen in Table 3, with the subdomains general physical self-concept, general self-concept and physical attractiveness particularly prominent. In contrast, their per- ception of strength is higher than that of the other weightlifters.

Table 3. Descriptive of CAF variables on the basis of the ESM categorization.

\begin{tabular}{lllllll}
\hline & \multicolumn{1}{c}{ Category 1 } & Category 2 & Category 3 \\
\cline { 2 - 7 } & $M$ & $S D$ & $M$ & $S D$ & $M$ & $S D$ \\
\hline Sport ability & 25.36 & 4.65 & 24.84 & 3.13 & 24 & 8.48 \\
Physical condition & 23.36 & 5.06 & 22.94 & 3.73 & 22.5 & 4.94 \\
Physical attractiveness & 23.09 & 7.06 & 23.36 & 4.57 & 21 & 1.41 \\
Strenght & 24.54 & 3.64 & 23.89 & 4.17 & 26.5 & 4.94 \\
General physical self-concept & 26.27 & 4.83 & 25.47 & 4.15 & 22.5 & 3.53 \\
General self-concept & 25.18 & 3.400 & 26.15 & 3.41 & 22.5 & .70 \\
\hline
\end{tabular}

The correlation between muscle dissatisfaction and Physical Self-concept

The ESM categories subdomain correlates in a significant and positive manner with the five subdomains that comprise the ESM $(r=.38-.64)$, with the highest correlations being those found with bodybuilding dependency $(r=.64, p<.01)$ and muscle checking $(r=.47, p<.01)$, a subdomain that also correlates with substance use $(r=.35, p<.05)$. In addition, positive and significant correlations were observed between general physical self-concept and the subdomains of sport ability $(r=.55, p<.01)$ physical condition $(r=.51, p<.01)$, strength $(r=.54, p<.01)$ and physical attractiveness $(r=.77$, $p<.01)$. Physical attractiveness also correlated with physical condition $(r=.55, p<.01)$, general self-concept $(r=.59, p<$ $.01)$ and strength $(r=.53, p<.01)$. Finally, a correlation between general self-concept and general physical self-concept $(r=.59, p=.01)$ was also noted, and between general physical self-concept and muscle (dis)satisfaction, with the correlation being negative and significant in this case $(r=-.43, p<$ $.05)$.

Table 4. Correlations between Cuestionario de Autoconcepto Físico and Escala de Satisfacción Muscular.

1. ESM Categories

2. Sport ability

3. Physical condition

4. Physical attractiveness

5. Strength

6. General physical self-concept

7. General self-concept

8. Bodybuilding dependence

9. Muscle checking

10. Substance use

11. Injury

12. Muscle (dis)satisfaction

\section{Discussion}

The aim of this study was to detect the presence of MD symptoms in male weightlifters. Four hypotheses were proposed with a view to achieving this objective. The first pos- ited that in an activity in which muscle development is a key factor, as is the case in weightlifting, some athletes would show DM symptoms, as it may be muscular distortion and body dissatisfaction as a result.

As regards the type of physical activity, weightlifting is not an aerobic sport, a type of activity in which the highest 
correlations are found with body dissatisfaction and physical self-concept, (Ruíz de Azúa, Goñi \& Rodríguez, 2005). There may, however, be a negative correlation founded on the characteristics of the sport, due to the creation of competition categories based on a specific weight (Ruíz de Azúa et al., 2005), although this is not as important as in sports in which aesthetic appearance is valued.

As regards the aforementioned muscle distortion, the data shows that all the participants have a real FFMI (Kouri et al., 1995) that is higher than their perceived FFMI, and that they want a higher FFMI than they actually have (real FFMI), in keeping with other studies (Murray et al., 2012). This may be attributable to the fact that expectations among men have always taken muscle development as their focus (Meesters, Muris, Hoefnagels \& Van Gemert, 2007; Menees, 2010; Wilson, 2010).

In view of the discrepancy between the real FFMI and the desired FFMI, it was noted that the participants in ESM category 3, who scored 58 points or more in the ESM and were therefore moderately dissatisfied with their muscularity, had a higher real FFMI $\left(M=22.80 \mathrm{~kg} / \mathrm{m}^{2}\right)$ and a lower perceived FFMI $\left(M=15 \mathrm{~kg} / \mathrm{m}^{2}\right)$ than the other athletes, which supports the first hypothesis. These differences reveal a distortion in the level of muscularity between the participants in this category of $7.8 \mathrm{~kg} / \mathrm{m}^{2}$. MD is said to exist when said difference exceeds $3 \mathrm{~kg} / \mathrm{m}^{2}$ (González-Martí, 2012; Pope et al., 2000). Studies conducted in different sports have shown that athletes want to be more muscular than they actually are (Cohane \& Pope, 2000; González-Martí, 2012; Grammas \& Schwartz, 2009; Gruber et al., 1999; Kelly, Neufeld \& Musher-Eizenman, 2010; Pope et al., 2000), results that correspond with the FFMI of 20 participants in this research study. The results do not tally, however, with the data presented by Urpadilleta, Aspavlo, Masse \& Docteur (2010) in research conducted with swimmers, in which the FFMI desired by the participants was similar to the FFMI they perceived (Urpadilleta, Aspavlo, Masse \& Docteur, 2010).

The problem that may derive from a divergence between the desired FFMI and the perceived FFMI is muscle dissatisfaction. Said dissatisfaction correlates with a dependency on exercise (González-Martí et al., 2012), which is more commonly seen in athletes who are below their ideal weight (Arbinaga, 2005) and who want to increase muscle mass rather than fat (Ochner, Gray \& Brickner, 2009). It is not often the case that weightlifters are below their ideal weight, though they may express a wish to be more muscular than they actually are, largely because they are dissatisfied with their strength or with the weights they are capable of moving (Hale et al., 2010) or because they are dissatisfied with the size of their muscles.

The second hypothesis put forward was that athletes suffering from MD would use substances to alleviate the body distortion from which they suffer, with the aim of improving their appearance. The data shows that the entire sample takes substances for this reason, mainly with the aim of gaining weight, an increase that equates to the building up of muscle mass. The second hypothesis can thus be accepted, given that one of the reasons why athletes use substances is to reduce muscle dissatisfaction, as stated by Babusa et al. (2012) and Cafri \& Thompson (2004). Another possible reason for consuming these products is the low perception that athletes may have of their strength (Sokolova, GonzálezMartí, Contreras \& Fernández, 2013; González-Martí, Fernández, Hernández-Martínez \& Contreras, 2014) due to the nature of the sport of weightlifting, although this is not the case in these participants.

The study's third hypothesis proposed that weightlifters suffering from MD would engage in obsessive bodychecking behaviours in an effort to detect any increase in their muscularity, either by using scales, looking in a mirror or comparing themselves with colleagues. While these behaviours may be common in some athletes, it does not necessarily mean they have a disorder, though it is considered a problem when they check themselves excessively or such behaviour becomes compulsive (Alfano, Hildebrandt, Bannon, Walker \& Walton, 2011). Such behaviours may also result in obsessive symptoms (Wolke \& Saupona, 2008), as displayed by category 3 participants, who are moderately dissatisfied with their muscularity and who check their muscles whenever possible. These behaviours are linked to weight and body shape concerns and to depression and the use of AAS (Walker, Andreson \& Hildebrandt, 2009), which are also all associated with possible muscle dissatisfaction.

In this study, all the category 3 athletes said that they checked themselves in the mirror for body changes three times a day or "as many times as possible", which supports the hypothesis put forward. Furthermore, $50 \%$ of them said they compared their bodies with those of their colleagues, indicating that they do so "too many times a day", which suggests they have less self-confidence than weightlifters who do not compare themselves to others (Arbinaga \& Caracuel, 2005).

The fourth hypothesis was that participants with MD would have low physical self-concept as a result of the muscle dissatisfaction from which they suffer. The data supports this theory and confirms that the hypothesis is correct, as athletes who are moderately dissatisfied with their muscularity (ESM category 3), have low self-perception in all the CAF subdomains, especially physical attractiveness. As regards physical self-concept, it was noted that it refers both to the subjective perception that a person has of their abilities or physical condition and to their appearance-related feelings and perceptions. It can thus be concluded that the value that a person attaches to their physique impacts on their physical self-concept and, therefore, on their general self-concept.

The study also revealed correlations between general physical self-concept and the subdomains sport ability $(r=$ $.55)$, physical condition $(r=.51)$, strength $(r=.54)$ and physical attractiveness $(r=.77)$, which corresponds with research conducted by González-Martí et al., (2014) and Moreno, Moreno \& Cervelló (2009). One exception detected in category 3 participants (moderately dissatisfied with their muscu- 
larity) was the high score they recorded in their perception of strength. This may be due to the amount of training they do, which may also help athletes alleviate the body distortion and muscle dissatisfaction from which they suffer, hence the correlation detected between the ESM categories subdomain and bodybuilding dependence $(r=.64)$ and muscle checking $(r=.47)$, and the existence of correlations between the muscle checking and substance use $(r=.35)$ subdomains. This demonstrates that the higher the ESM category to which the athlete belongs, the greater their dependency on bodybuilding, the more muscle checking behaviours they will engage in and the more substances they will consume with the purpose of improving their appearance, all of which is linked to muscle dissatisfaction.

Continuing on the theme of muscle dissatisfaction as one of the main symptoms of DM, the study revealed negative correlations between muscle (dis)satisfaction and general physical self-concept, which can be linked to low self-esteem (Wolke \& Saupona, 2008), low perception of physical attractiveness and low physical self-concept. This data corresponds with the findings presented by Sokolova et al. (2013), which show that MD sufferers have a low perception of their physical attractiveness and low self-perception. It also corresponds with the negative correlation between general selfconcept and physical attractiveness detected in a study car-

\section{References}

Alfano, L., Hildebrant, T., Bannon, K., Walker, C., \& Walton, K. E. (2011). The impact of gender on the assessment of body checking behavior. Body Image, 8, 20-25. doi: 10.1016/j.bodyim.2010.09.005

American Psychiatric Association (2014). Manual diagnóstico y estadístico de los trastornos mentales (DSM-5). [Diagnostic and Statistical Manual of Mental Disorders (DSM-5)]. 5a Ed. Arlington, VA, Asociación Americana de Psiquiatría.

Arbinaga, F. (2005). Varones noveles en el entrenamiento de musculación: un estudio piloto sobre ansiedad física social [Novice male body building training: a pilot study on social physical anxiety]. Kronos, 7, 33-11.

Arbinaga, F., \& Caracuel, J. C. (2005). Precompetición y Ansiedad en Fisicoculturistas [Precompetition and Anxiety in Bodybuilders]. Revista de Psicología del Deporte, 14(2), 195-208.

Babusa, B., Urbán, R., Czeglédi, E., \& Túry, F. (2012). Psychometric properties and construct validity of the Muscle Appearance Satisfaction Scale among Hungarian men. Body Image, 9, 155-162. doi: 10.1016/j.bodyim.2011.08.005

Baghurst, T., \& Lirgg, C. (2009). Characteristics of muscle dysmorphia in male football, weight training, and competitive natural and non-natural bodybuilding samples. Body Image, 6, 221-227. doi: 10.1016/j.bodyim.2009.03.002

Cafri, G., \& Thompson, K. J. (2004). Measuring Male body image: A Review of the Current Methodology. Psychology of the Men and Masculinity, 5(1), 18-29. doi: 10.1037/1524-9220.5.1.18

Cafri, G., Van der Berg, P., \& Thompson, J. K. (2006). Pursuit of Muscularity in Adolescent Boys: Relations among biopsychosocial variables and clinical outcomes. Journal of Clinical Child and Adolescent Psychology, 35(2), 283-291. doi: 10.1207/s15374424jccp3502_12

Cohane, G. H., \& Pope, H. G. (2000). Body Image in Boys: A Review of the Literature. International Journal of Eating Disorders, 29, 373-379. doi: 10.1002/eat.1033

Esco, M. R., Olson, M. S., \& Williford, H. N. (2005). Muscle Dysmorphia: An Emerging Body Image Concern in Men. National Strength and Conditioning Association, 27(6), 76-79. doi: 10.1519/00126548-20051200000012 ried out with adolescents (Fernández, Contreras, González \& Abellán, 2011).

\section{Conclusion}

The aim of this study was to detect the presence of MD symptoms in male weightlifters, which was proved by means of four hypotheses. Firstly, it was observed that athletes can display MD symptoms in engaging in an activity in which muscle development is a determining factor. It was also found that participants belonging to ESM category 3 used substances to increase their muscularity and demonstrated excessive muscle checking behaviours. Finally, these athletes were found to have a low perception of their physical attractiveness, a factor related to the possible body image distortion suffered by participants who were moderately dissatisfied with their muscularity and scored 58 points or more in the ESM.

With a view to investigating the subject in greater depth, future research into MD could focus on its appearance in athletes in a range of different sports and help to set out common criteria based on the specific characteristics of each sport. This would improve the prevention and/or detection of these types of disorders.

Fernández, J. G., Contreras, O. R., González, I., \& Abellán, J. (2011). El autoconcepto físico en Educación Secundaria. Diferencias en función del género y la edad [Physical self-concept in secondary education. Differences relation on the gender and age]. Revista Galego-Portuguesa de Psicoloxía e Educación, 19(1), 199-212.

Fox, K., \& Corbin, C. (1989). The physical self and processes in self-steem development. In Fox (Ed.), The physical self. From motivation to well-being. Champaign: Human Kinetics.

González-Martí, I. (2012). Elementos que integran el perfil de la persona afectada por Dismorfia Muscular (Vigorexia). Prevalencia del trastorno en fisicoculturistas y usuarios de la sala de musculación [Elements to take part in the profile of a person affected with Muscle Dysmorphia (Bigorexia). Prevalence of disorder in bodybuilders and weightlifters users gym] (Tesis doctoral inédita). Universidad de Castilla-La Mancha, Cuenca.

González-Martí, I., Fernández, J. G., \& Contreras, O. R. (2012). Contribución para el criterio diagnóstico de la Dismorfia Muscular (Vigorexia) [Contribution to the diagnosis criterion of muscle Dysmorphia (Bigorexia)]. Revista de Psicología del Deporte, 21(2), 351-358.

González-Martí, I., Fernández, J. G., Contreras, O. R., \& Mayville, S. B. (2012). Validation of a Spanish version of the Muscle Appearance Satisfaction Scale: Escala de Satisfacción Muscular. Body Image, 9, 517-523. doi: 10.1016/j.bodyim.2012.05.002

González-Martí, I., Fernández, J. G., Hernández-Martínez, A., \& Contreras, O. R. (2014). Physical perceptions and self-concept in athletes with muscle dysmorphia symptoms. The Spanish Journal of Psychology, 17(43), $1-7$.

Goñi, A., Ruíz de Azúa, S., \& Liberal, A. (2004). El autoconcepto físico y su medida. Las propiedades psicométricas de un nuevo cuestionario [Physical self-concept and their assessment. The psychometrics properties of a new questionnaire]. Revista de Psicología del Deporte, 13(2), 195213. Recovered http://ddd.uab.cat/pub/revpsidep/19885636v13n2p195.pdf

Grammas, D. L., \& Schwartz, J. P. (2009). Internalization of messages from society and perfectionism as predictor of male body image. Body Image, 6, 31-36. doi: 10.1016/j.bodyim.2008.10.002 
Grieve, F. G. (2007). A conceptual model of factors contributing to the development of muscle dysmorphia. Eating Disorders, 15, 63-80.

Gruber, A. J., Pope, H. G., Borowiecki, J., \& Cohane, G. (1999). The development of the Somatomorphic matrix: A bi-axial instrument for measuring body image in men and women. In T. S. Olds, J. Dollman, \& K. I. Norton (Eds.), Kinanthropometry VI. Sydney: International Society for the Advancement of Kinanthropometry.

Hale, B. D., Roth, A. D., Delong, R. E., \& Briggs, M. S. (2010). Exercise dependence and the drive for muscularity in male bodybuilders, power lifters, and fitness lifters. Body Image, 7, 234-239. doi: 10.1016/j.bodyim.2010.02.001

Jackson, A., \& Pollock, M. (1978). Generalized equations for predicting body density in man. British Journal Nutrition, 40, 497-504.

Kelly, C. C., Neufeld, J. M., \& Musher-Eizenman, D. (2010). Drive for thinness and drive for muscularity: Opposite ends of the continuum or separate constructs?. Body Image, 7, 74-77. doi: 10.1016/j.bodyim.2009.09.008

Kouri, E., Pope, H., Katz, D., \& Oliva, P. (1995). Fat-Free Mass index in Users and Nonusers of Anabolic-Androgenic. Clinical Journal of Sports Medicine, 5, 223-228. doi: 10.1097/00042752-199510000-00003

Marfell-Jones, M., Olds, T., Stewart, A., \& Carter, L. (2006). International Standards for Anthropometric Assessment. ISAK: Potchefstroom, South Africa.

Meesters, C., Muris, P., Hoefnagels, C., \& Van Gemert, M. (2007). Social and family correlates of eating problems and muscle preoccupation in Young adolescents. Eating Behaviors, 8, 83-90. doi: 10.1016/j.eatbeh. 2006.02.002

Menees, L. M. (2010). Examining the Relationship between Criticism and Muscle Dysmorphia Symptomotology in Collegiate Men. Master Theses and Specialist Projects. Paper, 179. Recovered from http:/ / digitalcommons.wku.edu/theses/179.

Moreno, R., Moreno, J. A., \& Cervelló, E. (2009). Relación del autoconcepto físico con las conductas de consumo de alcohol y tabaco en jóvenes adolescentes [Relationship of physical self-concept with the behaviours of alcohol and tobacco in adolescent girls]. Adicciones, 21(2), 147-154.
Murray, S. B., Rieger, E., Hildebrant, T., Karlov, L., Rusell, J., Boon, E., Dawson, R. T., \& Touyz, S.W. (2012). A comparison of eating, exercise, shape, and weight related symptomatology in males with muscle dysmorphia and anorexia nervosa. Body Image, 9, 193-200. doi: 10.1016/j.bodyim.2012.01.008

Ochner, C. N., Gray, J. A., \& Brickner, K. (2009). The development and initial validation of a new measure of male body dissatisfaction. Eating Behaviors, 10, 197-201. doi: 10.1016/j.eatbeh.2009.06.002

Pope, H. G., Phillips, K., \& Olivardia, R. (2000). The Adonis Complex. How to Identify, Treat, and Prevent Body obsession in Men and Boys. New York. A Touchstones Book.

Ruíz de Azúa, S., Goñi, A., \& Rodríguez, A. (2005). Variables socioculturales en la construcción del autoconcepto físico [Sociocultural variables in the construction of physical self-concept.]. Cultura y Educación, 17(3), 225-338.

Sokolova, M. V., González-Martí, I., Contreras, O. R., \& Fernández, J. G., (2013). A Case Study of Muscle Dysmorphia Disorder Diagnostics. Expert Systems with Applications, 40, 4226-4231. doi: 10.1016/j.eswa.2013.01.023

Urpadilleta, I., Aspalov, D., Masse, L., \& Docteur, A. (2010). Use of a picture distortion technique to examine perceptive and ideal body image in male and female competitive swimmers. Psychology of Sport and Exercise, $11,568-573$.

Walker, C., Andreson, D. A., \& Hildebrandt, T. (2009). Body checking behaviors in men. Body Image, 6, 164-170. doi: 10.1016/j.bodyim.2009.05.001

Wilson, S. A. (2010). The Effects of Picture Presentation on Male Body Shame and Muscle Dysmorphia. Master Theses and Specialist Projects. Papers, $141 . \quad$ Recovered from http://digitalcommons.wku.edu/theses/141.

Wolke, D., \& Saupona, M. (2008). Big men feeling small: Childhood bullying experience, muscle dysmorphia and other mental health problems in bodybuilders. Psychology of Sport and Exercise, 9, 595-604. doi: 10.1016/j.psychsport.2007.10.002

(Article received: 21-07-2015; revised: 08-02-2016; accepted: 26-03-2016) 